\title{
Inertial Taylor Rules: The Benefit of Signaling Future Policy
}

\author{
Charles T. Carlstrom and Timothy S. Fuerst
}

\begin{abstract}
This article traces the consequences of an energy shock on the economy under two different monetary policy rules: (i) a standard Taylor rule, where the Fed responds to inflation and the output gap, and (ii) a Taylor rule with inertia, where the Fed moves slowly to the rate predicted by the standard rule. The authors show that, with both sticky wages and sticky prices, the outcome of an inertial Taylor rule is superior to that of the standard rule, in the sense that inflation is lower and output is higher following an adverse energy shock. However, if prices alone are sticky, the results are less clear and the standard rule delivers substantially less inflation than the inertial rule in the short run. (JEL E52, E61)
\end{abstract}

Federal Reserve Bank of St. Louis Review, May/June 2008, 90(3, Part 2), pp. 193-203.

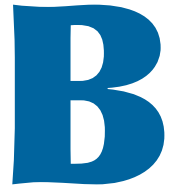
efore exiting an expressway, a cautious driver always signals his intention by switching on his turn signal well in advance of turning because he understands that other drivers' behavior will be affected by what they anticipate he will do. This commonplace example may speak metaphorically to central bank policy: If market participants are forward looking, then it may be important for the central bank to signal future policy moves.

Starting in June 2004, the FOMC changed its language to indicate that existing policy accommodation would be removed at a "measured pace," strongly signaling the direction of future Fed policy. But why adjust partway by signaling future policy instead of going all the way more quickly? Likewise, why increase the funds rate 25 basis points at each of 10 policy meetings, instead of making five moves of 50 basis points, or, for that matter, one move of 250 basis points? What are the advantages of a measured pace?
One way to describe Fed policy is with a simple Taylor (1993) rule in which monetary policy responds to inflation and the output gap. Clearly, the Fed does not automatically adjust policy according to the prescriptions of the rule. Nevertheless, there is substantial empirical evidence that broad movements in the funds rate are well tracked by a simple Taylor rule. But this evidence also suggests that the Fed adjusts the funds rate much more slowly than the standard Taylor rule prescribes. That is, although funds rate movements are typically in the direction suggested by the rule, these movements are only partial; thus, it takes a series of policy moves to reach the level a standard Taylor rule suggests. This type of Taylor rule is said to be inertial because it changes slowly and today's funds rate depends on yesterday's funds rate.

One way to think about an inertial Taylor rule is that policy consists of both the funds rate today and the expected path of the funds rate. Without inertia, policy moves more immediately and does not indicate where the funds rate is

Charles T. Carlstrom is a senior economic advisor at the Federal Reserve Bank of Cleveland. Timothy S. Fuerst is a professor of economics at Bowling Green State University.

(C) 2008, The Federal Reserve Bank of St. Louis. The views expressed in this article are those of the author(s) and do not necessarily reflect the views of the Federal Reserve System, the Board of Governors, or the regional Federal Reserve Banks. Articles may be reprinted, reproduced, published, distributed, displayed, and transmitted in their entirety if copyright notice, author name(s), and full citation are included. Abstracts, synopses, and other derivative works may be made only with prior written permission of the Federal Reserve Bank of St. Louis. 


\section{Figure 1}

\section{Inertial and Non-Inertial Taylor Rules}

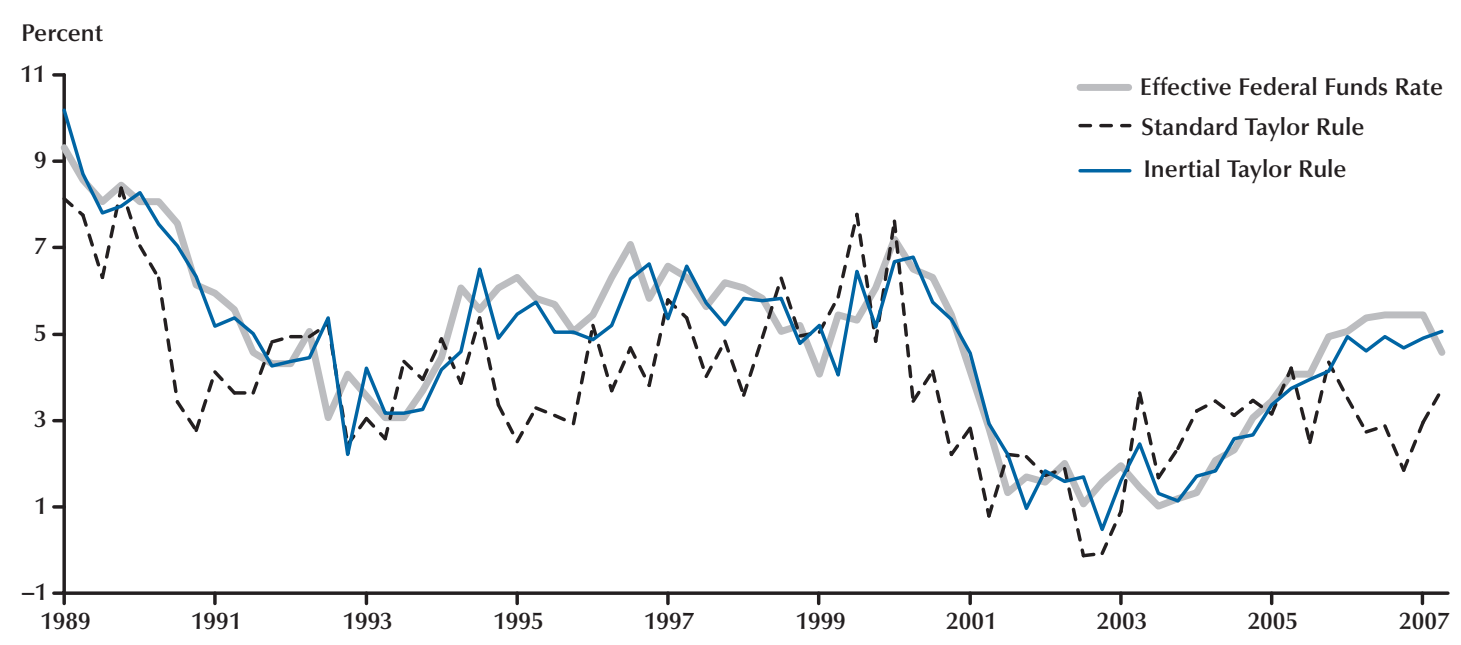

NOTE: The standard (non-inertial) Taylor rule is adapted from Taylor (1993). The effective federal funds rate is the rate on the last day of each quarter. The inertial (partial-adjustment) Taylor rule is the weighted average of last quarter's federal funds rate and the target Taylor rule. The exact form of both Taylor rules comes from Kozicki (1999).

SOURCE: U.S. Department of Commerce, Bureau of Economic Analysis; Bloomberg Financial Services; Board of Governors of the Federal Reserve System, Federal Reserve Statistical Release H.15, "Selected Interest Rates"; and the Congressional Budget Office.

likely to head. ${ }^{1}$ This article shows, in the context of a standard, quantitative, dynamic New Keynesian model, that it is beneficial for policy accommodation to be removed slowly instead of in one-or a few-large moves. That is, an inertial Taylor rule frequently delivers a better outcome than a non-inertial rule.

In particular, we trace the consequences of an energy shock on the economy under two different monetary policy rules: a standard Taylor rule, where the Fed responds to inflation and the output gap, and an inertial Taylor rule, where the Fed moves slowly to the rate predicted by the standard rule. We show that with both sticky wages and sticky prices, an inertial (partialadjustment) Taylor rule's outcome is superior to that of a standard rule, in the sense that inflation is lower and output higher following an adverse energy shock. However, if prices alone are sticky,

1 Of course, even with a non-inertial Taylor rule, one will anticipate future funds rate movements to the extent that future inflation and the output gap are forecasted. the results are less clear and the standard rule delivers substantially less inflation than the inertial rule in the short run.

\section{THE TAYLOR RULE}

The Taylor rule has had a big impact in both monetary policy circles and academic economic research. Figure 1 suggests why. The rule seems to track broad policy moves since 1987 very successfully, which seems remarkable because it is so simple: It is set according to only four components: The first is the Fed's long-term inflation target and the second is the "natural" or long-term real (inflation-adjusted) federal funds interest rate. The sum of these first two factors determines the long-run (nominal) federal funds rate, which amounted to 4 percent annually in Taylor's original rule. The two remaining factors, the current output gap and the four-quarter inflation rate, address the way policy should respond to changing circumstances in the short run. 
The Taylor rule prescribes that the Fed "lean against the wind" when setting interest rates; that is, it should raise rates when current output surpasses potential. It prescribes a similar response to inflation-raise interest rates when the inflation rate over the past year exceeds its long-term target.

But mere leaning is not enough when it comes to inflation. Taylor cautioned that interest rates must rise by more than the increase in inflation. Given that nominal interest rates naturally increase one-for-one with movements in anticipated inflation (leaving the real rate unchanged), just increasing the funds rate one-for-one with increases in inflation is like treading water. Therefore, the Fed must increase the real funds rate in response to the rise in inflation to make any headway. This more-than-proportional response of the nominal funds rate to inflation, known as the Taylor principle, therefore prescribes that the real federal funds rate should be made greater than the natural rate of interest whenever inflation is above target.

In the simplest form of the rule, Taylor argued that the Fed should increase the real funds rate by half a percentage point for every percentage point that inflation is above target or output is above potential. This implies that the nominal funds rate should increase by 1.5 percent for every percentage point increase in inflation. (Likewise, the Fed should decrease the real funds rate by the same amount for deviations below either target or potential.) Thus, Taylor felt that monetary policy (in terms of the real funds rate) should respond equally (in terms of the real interest rate) to inflation and output deviations. But the exact weights are not crucial. Empirical evidence suggests that the Fed has responded to output gap deviations (at least since 1983) a little less than Taylor had assumed:

$$
i_{t}^{*}=2.32+1.44 *\left(\pi_{t}-\pi^{*}\right)+0.15^{*} \text { outputgap }_{t} .
$$

Figure 1 plots this rule and shows that it remains below or above the actual funds rate for long periods. One reason for these long misses is that the FOMC does not change the funds rate as often or as dramatically as the standard Taylor rule suggests. Instead, the actual funds rate exhibits a lot of inertia, suggesting that an inertial Taylor rule might be a better fit. Here the Fed also looks at the past funds rate in setting its target. The inertial Taylor rule is given by

$$
i_{t}^{P A}=0.76 * i_{t-1}+0.24 * i_{t}^{*}
$$

where $i_{t-1}$ is last quarter's funds rate (measured by the federal funds rate on the last day of the quarter) and $i^{*}$ is the target rate (the rate suggested by the Taylor rule without inertia). Figure 1 also plots this inertial rule. The baseline rule without inertia is basically a longer-run target that provides guidance for where the funds rate will eventually end up. The data suggest that instead of moving to the target immediately, the Fed moves only 24 percent of the way there each quarter. Figure 1 clearly shows that this partialadjustment Taylor rule tracks the actual funds rate very closely. Another way of thinking about the partial-adjustment formulation is that, instead of reacting to today's inflation and the output gap, the Federal Open Market Committee (FOMC) reacts to a weighted average of today's and all past inflation and output gaps.

The discussion that follows shows that, with sticky prices and sticky wages, a partialadjustment Taylor rule delivers better inflation and output outcomes than the traditional Taylor rule. This is shown in the context of an oil shock that reduces output and increases inflation.

\section{OIL PRICES AND MONETARY POLICY: A COMPUTABLE GENERAL-EQUILIBRIUM MODEL}

To ascertain whether an inertial or non-inertial Taylor rule is better, we need a calibrated computable general-equilibrium model. Here we sketch the model used for our simulations; we describe it more fully in the appendix, along with our calibration of its parameters. Oil is an important input in manufacturing (and, perhaps to a lesser extent, in services). Oil price increases will therefore reduce output and (for a given monetary policy) increase prices. The rise in prices is not 
instantaneous, however; the evidence suggests that prices are sticky and adjust slowly and that wages are sticky as well. Both these forms of nominal stickiness imply that output will not respond efficiently and will differ from its firstbest level (or potential). That is, if both prices and wages were perfectly flexible, the output gap would be zero.

A key issue in the analysis is, of course, the statement of monetary policy. For the benchmark simulation, we assume that policy is given by the standard (non-inertial) Taylor rule described in the previous section. For the inertial rule we use the partial-adjustment rate estimated by Kozicki (1999), where policy adjusts only 24 percent of the way to the rate predicted by the standard Taylor rule.

\section{MODEL SIMULATIONS}

Model simulations suggest that there may be an advantage in adjusting the funds rate slowly. Figure 2 answers these hypothetical questions: Holding everything else constant, how would inflation, interest rates, and output be expected to behave following a one-time 30 percent increase in oil prices? How would these variables behave if the Fed followed a non-inertial Taylor rule compared with an inertial Taylor rule? All variables are plotted as log deviations from trend. (For the funds rate and inflation, these are linear deviations from trend.)

With both rules, the oil shock tends to increase inflation. The standard Taylor rule suggests that policymakers raise the nominal interest rate to keep inflation from increasing even more. But with an inertial Taylor rule, this increase is smaller and spread out over time. Therefore, the difference between an inertial rule and noninertial rule is that the latter increases rates less today with a promise of future increases.

This promise to increase rates in the future is extremely important. With the inertial rule, the nominal funds rate lags behind the rule without inertia and peaks at a much lower level as well. This promise of future rate increases keeps inflation lower than the non-inertial rule as well. Sur- prisingly, the funds rate with inertia is always lower than the non-inertial Taylor rule; yet inflation, too, is always lower. This is because the stance of monetary policy is not given by the nominal funds rate but by the real, inflationadjusted funds rate. More precisely, the policy stance is given by how much the real, inflationadjusted funds rate deviates from the Wicksellian interest rate (the real interest rate that would prevail in the economy if there were no price or wage stickiness or, equivalently, if the output gap were always equal to zero). By construction, therefore, the Wicksellian rate is the same for both the inertial and non-inertial rules.

In the quarters immediately following an oil price increase, policy is much easier (the real rate is lower) for the inertial rule. However, this does not translate into more inflation today, because in later periods, policy is expected to be tighter for the inertial rule. A long period in the distant future, when policy is expected to be tighter, more than compensates (in terms of inflation outcomes) for the shorter period of time when policy was substantially easier. The true stance of monetary policy, therefore, is given not only by the real interest rate but also by the real rate's future path.

Although inversely related, the behavior of the output gap mirrors that of the real interest rate. In the beginning, the real interest rate is lower, making policy less restrictive for the inertial rule than it is for the non-inertial rule. Not surprisingly, during these periods, output and thus the output gap is higher for the inertial rules. In subsequent periods, things are reversed. The output gap is composed of two distortions, one arising from sticky prices and the other from sticky wages. The output gap from sticky prices is nearly identical for the two rules (although a little lower for the inertial rule). It is the gap arising from sticky wages that drives the difference between each rule's total output gap.

Inflation is a little lower in the inertial model because output and the output gap resulting from sticky prices are a little lower. Another way of thinking about inflation is that it is the present discounted value of all future marginal costs (the inverse of the markup). Current prices are determined by marginal cost, as it is today and is 


\section{Figure 2}

\section{Response to an Oil Shock (Sticky Prices and Sticky Wages)}

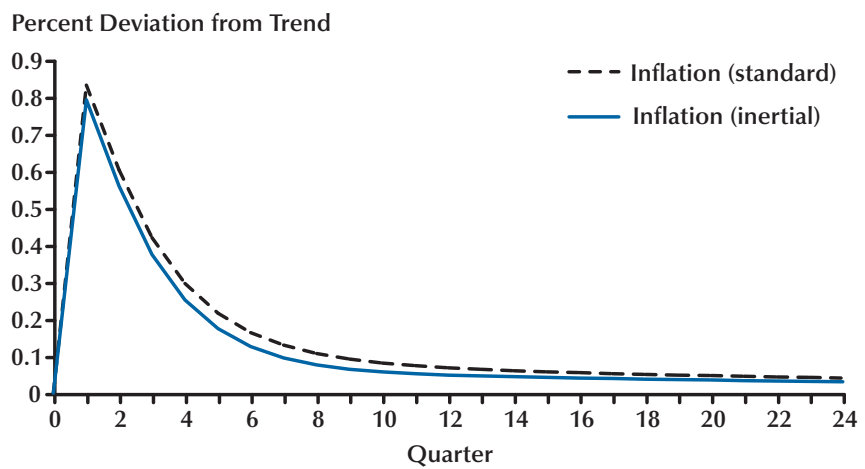

Percent Deviation from Trend

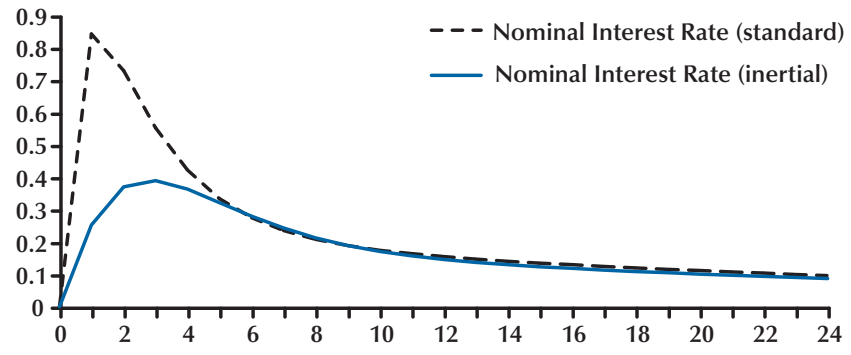

Percent Deviation from Trend

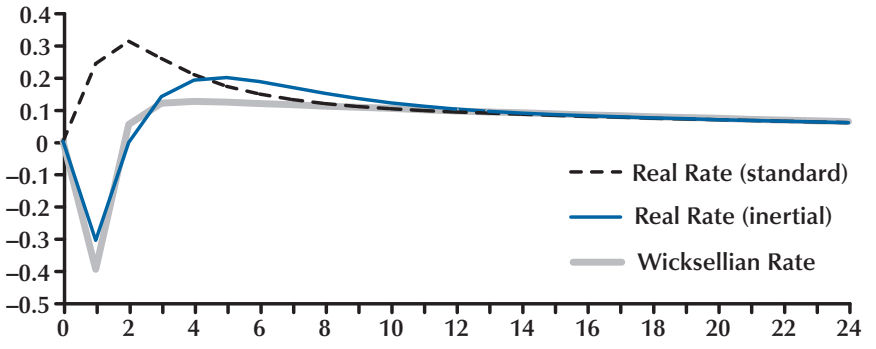

Percent Deviation from Trend

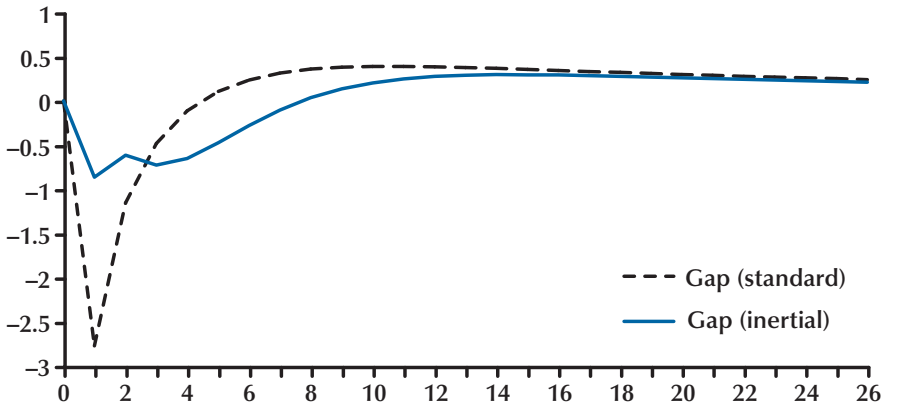

NOTE: Simulations are hypothetical responses to a 30 percent oil price shock, given that future oil prices behave as they have in the past. SOURCE: U.S. Department of Commerce, Bureau of Economic Analysis; U.S. Department of Labor, Bureau of Labor Statistics; Board of Governors of the Federal Reserve System, Federal Reserve Statistical Release H.15, "Selected Interest Rates"; and author's calculations. 
Figure 2, cont'd

\section{Response to an Oil Shock (Sticky Prices and Sticky Wages)}

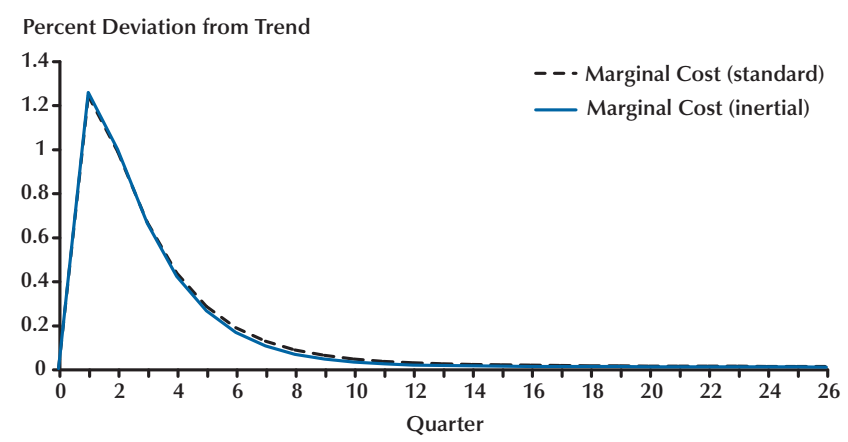

Percent Deviation from Trend
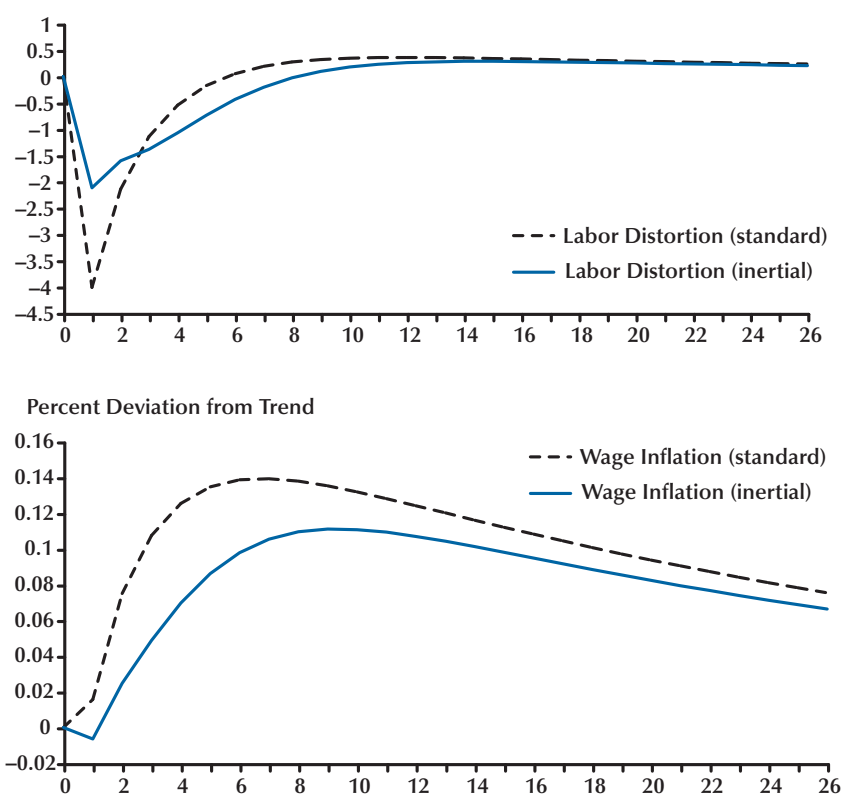

NOTE: Simulations are hypothetical responses to a 30 percent oil price shock, given that future oil prices behave as they have in the past. SOURCE: U.S. Department of Commerce, Bureau of Economic Analysis; U.S. Department of Labor, Bureau of Labor Statistics; Board of Governors of the Federal Reserve System, Federal Reserve Statistical Release H.15, "Selected Interest Rates"; and author's calculations. 


\section{Figure 3}

\section{Response to an Oil Shock (Sticky Prices Only)}

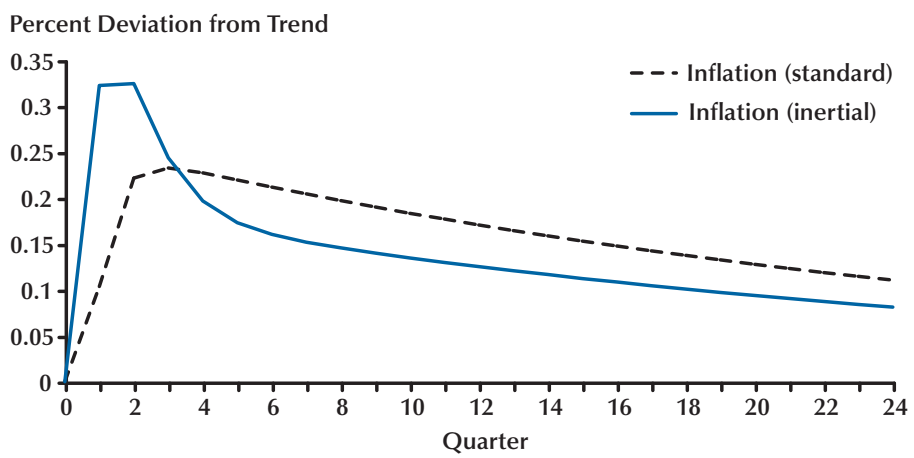

Percent Deviation from Trend

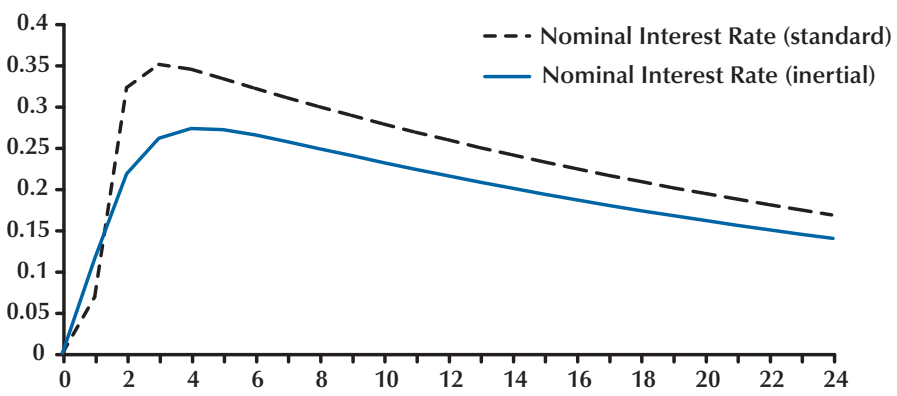

Percent Deviation from Trend

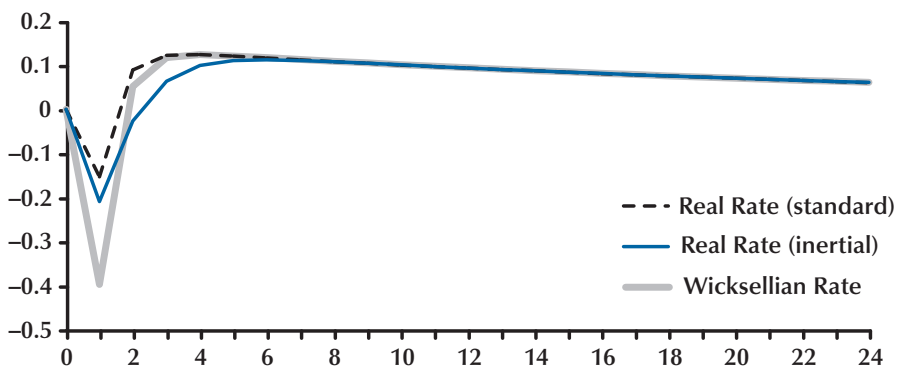

Percent Deviation from Trend

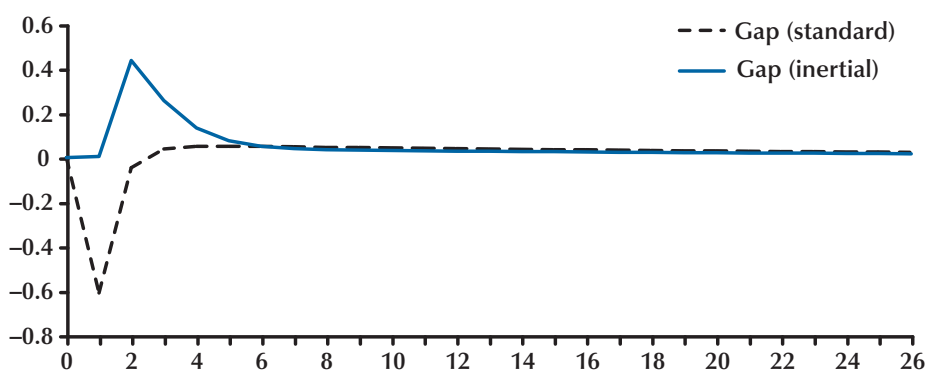

NOTE: Simulations are hypothetical responses to a 30 percent oil price shock, given that future oil prices behave as they have in the past. SOURCE: U.S. Department of Commerce, Bureau of Economic Analysis; U.S. Department of Labor, Bureau of Labor Statistics; Board of Governors of the Federal Reserve System, Federal Reserve Statistical Release H.15, "Selected Interest Rates"; and author's calculations. 
expected to be in the future. A larger markup (lower marginal cost) means that output is further below its efficient level, a negative output gap.

Like marginal cost for sticky prices, the monopoly distortion in labor markets measures the difference between the household's marginal rate of substitution and the real wage. A value of unity would mean no distortion, whereas a smaller value would imply a larger distortion and thus less output. Analogous to inflation, wage inflation is the present discounted value of all these future deviations. This distortion is what drives the difference between the output gap measures for the inertial and non-inertial Taylor rule simulations. Nominal wage inflation driven by differences in real wage growth is always lower for the inertial model. This fact implies that, in a present discounted sense, output is further below potential than it is in the model without inertia.

The difference between the part of the output gap driven by sticky prices versus that driven by sticky wages suggests that sticky wages may be crucial to the result that the inertial model appears to deliver better outcomes. A model with only sticky prices bears this out. Figure 3 graphs the outcomes for the model with only sticky prices. Inflation was everywhere lower for the inertial Taylor rule in the model with both sticky prices and sticky wages. But with only sticky prices, inflation is initially much higher for the inertial Taylor rule and output is further above potential. Because of the large inflation jump, nominal interest rates in the first few quarters after the energy shock are just as high for the inertial rule as for the non-inertial rule.

The importance of inertial Taylor rules is reminiscent of the benefits of forward-looking language in FOMC policy statements. With forward-looking language, the Fed moves today and signals where they intend to move in the future. Likewise, by influencing expectations, monetary policy operates off of both short- and long-term rates. An inertial Taylor rule basically states where the Fed moves today and where they are expected to move in the future.

\section{CONCLUSION}

This paper has shown that in a standard model with sticky wages and sticky prices, a Taylor rule with inertia delivers better outcomes than the standard Taylor rule without inertia. This result, however, depends on the stickiness of wages relative to prices. Recent work by Christiano, Eichenbaum, and Evans (2005) suggests the importance of sticky wages in explaining business cycle fluctuations. This lends support to the notion that the Fed implicitly follows an inertial Taylor rule because it delivers lower interest rates and inflation without worsening output significantly. In fact, for the first several quarters following an oil price increase, output is also higher for the inertial rule.

\section{REFERENCES}

Calvo, Guillermo. "Staggered Prices in a UtilityMaximizing Framework." Journal of Monetary Economics, September 1983, 12(3), pp. 383-98.

Christiano, Lawrence J.; Eichenbaum, Martin and Evans, Charles L. "Nominal Rigidities and the Dynamic Effects of a Shock to Monetary Policy." Journal of Political Economy, February 2005, 113(1), pp. 1-45.

Carlstrom, Charles T. and Fuerst, Timothy S. "Oil Prices, Monetary Policy, and Counterfactual Experiments." Journal of Money, Credit, and Banking, October 2006, 38(7), pp. 1945-58.

Erceg, Christopher J.; Henderson, Dale W. and Levin, Andrew T. "Optimal Monetary Policy with Staggered Wage and Price Contracts." Journal of Monetary Economics, October 2000, 46(2), pp. 281-313.

Kozicki, Sharon. "How Useful Are Taylor Rules for Monetary Policy?” Federal Reserve Bank of Kansas City Economic Review, Second Quarter 1999, 84(2), p. 5-33.

Kim, In-Moo and Loungani, Prakash. "The Role of Energy in Real Business Cycle Models." Journal of Monetary Economics, April 1992, 29(2), pp. 173-89. 
Taylor, John B. "Discretion versus Policy Rules in Practice.” Carnegie-Rochester Conference Series on Public Policy, December 1993, 39, pp. 195-214.

Walsh, Carl E. Monetary Theory and Policy.

Cambridge, MA: MIT Press, 2003.
Woodford, Michael. Interest and Prices. Princeton, NJ: Princeton University Press, 2003.

Yun, Tack. "Nominal Price Rigidity, Money Supply Endogeneity, and Business Cycles." Journal of Monetary Economics, July 1996, 37(2), pp. 345-70.

\section{APPENDIX}

\section{THE MODEL}

Apart from adding oil to the production technology, the underlying model is fairly standard. See Woodford (2003) and Walsh (2003) for details. The theoretical model described here consists of households and firms; we present the decision problems of each in turn.

\section{Households}

Households are infinitely lived, discounting the future at rate $\beta$. Their period-by-period utility function is given by

$$
U\left(C_{t}, L_{t}, \frac{M_{t+1}}{P_{t}}\right) \equiv \frac{C_{t}^{1-\sigma}}{1-\sigma}-\frac{L_{t}^{1+\gamma}}{1+\gamma}+V\left(\frac{M_{t+1}}{P_{t}}\right),
$$

where $\sigma>0, \gamma>0, V$ is increasing and concave, $C_{t}$ denotes consumption, $L_{t}$ denotes labor, and $M_{t+1} / P_{t}$ denotes real cash balances that can facilitate time- $t$ transactions. The household begins period $t$ with $M_{t}$ cash balances and $B_{t-1}$ one-period nominal bonds that pay $R_{t-1}$ gross interest. With $w_{t}$ denoting the real wage, $P_{t}$ the price level, and $X_{t}$ the time- $t$ monetary injection, the household's intertemporal budget constraint is given by

$$
P_{t} C_{t}+B_{t}+M_{t+1} \leq M_{t}+R_{t-1} B_{t-1}+P_{t} w_{t} L_{t}+X_{t}
$$

The household's portfolio choice is given by

$$
\begin{aligned}
& \frac{V^{\prime}\left(M_{t+1} / P_{t}\right)}{C_{t}^{-\sigma}}=\frac{R_{t}-1}{R_{t}} \\
& C_{t}^{-\sigma}=R_{t} \beta C_{t+1}^{-\sigma} / \pi_{t+1} .
\end{aligned}
$$

Following Erceg, Henderson, and Levin (2000), we assume that households are monopolistic suppliers of labor and that nominal wages are adjusted as in Calvo (1983). In this case, labor-supply behavior is given by

$$
C_{t}^{\sigma} L_{t}^{\gamma}=Z h_{t} W_{t}
$$

It is easy to see that the wage elasticity of labor demand in this model is $1 / \gamma$. The variable $Z h_{t}$ in this labor demand equation is the monopoly distortion because it measures the difference between the household's marginal rate of substitution and the real wage. In the case of perfectly flexible but monopolistic wages, $Z h_{t}=Z h$ is constant and less than unity. The smaller $Z h$ is, the greater is the monopoly power. In the case of sticky nominal wages, $Z h_{t}$ is variable and moves in response to the 


\section{Carlstrom and Fuerst}

real and nominal shocks hitting the economy. Erceg, Henderson, and Levin (2000) demonstrate that in log deviations, nominal wage adjustment is given by

$$
\pi_{t}^{W}=\lambda^{W} z h_{t}+\beta \pi_{t+1}^{W},
$$

where $\pi_{t}^{W}$ is time- $t$ net nominal wage growth and $z h_{t}$ denotes the log deviation from the steady state.

\section{Firms}

The firms in the model utilize labor services, $L_{t}$, from households and energy, $E_{t}$, from external sources to produce the final good using the constant elasticity of substitution (CES) technology:

$$
Y=f(L, E) \equiv\left[(1-a) L^{1-\rho}+a E^{1-\rho}\right]^{1 /(1-\rho)} .
$$

The real energy price is equal to $p_{t}^{e}$ so that a firm's nominal profits are given by

$$
\text { profits }=P_{t}\left(Y_{t}-w_{t} L_{t}-p_{t}^{e} E_{t}\right) .
$$

The firm is a monopolistic producer of these goods, implying that labor will be paid below its marginal product. Let $Z_{t}$ denote marginal cost so that we have

$$
\begin{aligned}
& w_{t}=Z_{t} f_{L}(t) \\
& p_{t}^{e}=Z_{t} f_{E}(t) .
\end{aligned}
$$

The variable $Z_{t}$ is the monopoly distortion as it measures how far the firm's marginal products differ from the real factor prices. In the case of perfectly flexible but monopolistic prices, $Z_{t}=Z$ is constant and less than unity. The smaller $Z$ is, the greater is the monopoly power. In the case of sticky prices, $Z_{t}$ is variable and moves in response to the real and nominal shocks hitting the economy. Yun (1996) demonstrates that in log deviations, nominal price adjustment is given by

$$
\pi_{t}=\lambda z_{t}+\beta \pi_{t+1},
$$

where $\pi_{t}$ is time- $t$ nominal price growth (as a deviation from steady-state nominal price growth) and lower case $z_{t}$ denotes the log deviation from the steady state.

\section{Equilibrium and Policy}

There are four markets in this theoretical model: labor, goods, bonds, and money. The respective market-clearing conditions include $C_{t}=Y_{t}-p_{t}^{e} E_{t}$ and $B_{t}=0$. The money market clears with the household holding the per capita money supply intertemporally.

\section{Calibration}

We set parameter values consistent with empirical estimates for a quarterly model. Preference parameters are given by $\beta=0.99$ (implying a 4 percent annual steady-state real rate of return), $\sigma=2$, and $\gamma=3$. The latter values are consistent with microeconomic evidence of fairly inelastic savings and labor supply behavior. Because monetary policy is given by an interest rate targeting procedure, the nature of money's utility is irrelevant. Finally, we assume that prices and nominal wage levels can be adjusted on average every 2.9 quarters. Given the other preference parameters, this implies $\lambda=0.19$ and $\lambda^{w}=0.0146$. For the model with sticky prices only, $\lambda^{w}=1,000$. 
As for firms, the elasticity of substitution between oil and labor is equal to $1 / \rho$. Consistent with empirical estimates, we set this elasticity to 0.59 , or $\rho=1.7$. (See Kim and Loungani, 1992.) The share parameter, $a$, is set to 0.02 . This implies a share of energy in total output of 6 percent (consistent with its share in 1989).

The (logged) real price of oil is given by an exogenous AR(2) process:

$$
p_{t}^{e}=a_{1} p_{t-1}^{e}+a_{2} p_{t-2}^{e}+\varepsilon_{t} .
$$

Estimating this process yields $a_{1}=1.12$ and $a_{2}=-15$.

Finally, recall that monetary policy in the baseline experiment is given by

$$
R_{t}=(1-\rho) R_{s s}+\rho R_{t-1}+(1-\rho)\left(\tau \pi_{t}+\tau_{g} \text { outputgap }_{t}\right),
$$

where

$$
\text { outputgap }_{t}=\frac{\left(z_{t}+z h_{t}\right)}{(\gamma+\sigma)} .
$$

Empirical evidence presented in Kozicki (1999) suggests that, since 1983, the coefficients in this monetary policy rule are $\tau=1.44$ and $\tau_{g}=0.14$. For the non-inertial Taylor rule, $\rho=0$; whereas, for the inertial Taylor rule, $\rho=0.76$. 
